\title{
BUDISMO PRIMORDIAL: HISTÓRIAS REM(C)ONTADAS
}

\author{
Alexsânder Nakaóka Elias ${ }^{1}$
}

\section{Preâmbulo: Percursos verbo-visuais}

O presente trabalho tem o intuito de relatar minha experiência etnográfica junto à comunidade Honmon Butsuryu-shu (HBS), uma importante corrente do Budismo japonês e a primeira a alcançar as terras tupiniquins, através do sacerdote Ibaragui Nissui Shounin, no ano de 1908.

O artigo é um singelo substrato da minha pesquisa de campo, realizada em maio de 2014 (para o Doutorado junto ao Programa de Pós-graduação em Antropologia Social da Unicamp), na qual, juntamente com uma caravana brasileira e japonesa, composta por sacerdotes e fiéis, pude acompanhar o chamado Caminho Primordial do Budismo, passando por diversos templos no Japão (país de origem da HBS), e pelas cidades sagradas da religião, na Índia e no Nepal (local do surgimento do Budismo).

No contexto desta pesquisa etnográfica, fiz uso do método de observação, do registro de narrativas e, principalmente, de imagens fotográficas. Com relação ao uso da fotografia, o intuito é o de explorar a potencialidade das imagens fotográficas para compor uma etnografia visual da referida comunidade budista japonesa.

Tal experiência consiste, de fato, em uma continuação da minha pesquisa de mestrado. Após dois anos de intenso convívio com a comunidade HBS do Brasil (de meados de 2011 até 2013), sendo recebido em três períodos distintos na Catedral Nikkyoji, o maior dos 10 templos desta religião no país, me deparei com um acervo que ultrapassava 4.000 fotografias, além de ter reunido mais de 10 horas de gravações (entre entrevistas, reuniões, cultos e conversas informais).

Tendo em mãos este vasto material verbo-imagético, percebi a necessidade de organizar tal acervo. Para tanto, utilizei-me inicialmente da imagem da mesa de montagem de Aby Warburg ${ }^{2}$, que em um dos seus inovadores projetos (chamado Atlas Mnemosyne e realizado entre 1924 e 1929), reuniu "todos os objetos de sua pesquisa em

\footnotetext{
${ }^{1}$ Universidade Estadual de Campinas, Brasil.

${ }^{2}$ Abraham Moritz Warburg (Hamburgo, 13/06/1866 - 26/10/1929), conhecido pela alcunha de Aby Warburg, foi um historiador da arte alemão, conhecido notadamente por organizar uma grandiosa Biblioteca, que reunia uma vasta coleção. Os critérios utilizados por Warburg fugiam às tradicionais regras de sistematização. Para organizar seu acervo, ele fazia uso do que chamou de "lei da boa vizinhança".
} 
um dispositivo de 'painéis móveis' constantemente montados, desmontados, remontados 3 ". Nesta obra, cíclica e inacabada, imagens heterogêneas dialogam entre si, formando e reformulando sentidos, ideias e sensações.

A minha mesa de montagem, que difere um pouco daquela organizada pelo historiador da arte alemão (já que a organizei por meio de um computador), parte do mesmo pressuposto, a saber que imagens distintas podem se (co)relacionar, gerar um sentido e, depois, ao se reorganizarem, trazer à tona outras constatações e significações.

Dessa forma, agrupei e ordenei meu conjunto fotográfico em torno de 13 temáticas. Para tal ordenação, inicialmente (e sem conseguir escapar a uma possível arbitrariedade) escolhi as fotografias mais adequadas, utilizando para isso critérios técnicos e estéticos. As fotos que apresentavam desfoque, sub-exposição, superexposição, mal enquadramento (ou outro problema da mesma natureza), assim como imagens "repetidas", não foram eleitas para análise.

Após selecionar as imagens seguindo tais critérios (técnicos/estéticos) e organizá-los, percebi, através de uma análise minuciosa (das fotografias, da doutrina da HBS, das entrevistas e do diário produzido na pesquisa de campo), que a emanação da oração, doutrina e imagem sagrada Namumyouhourenguekyou ${ }^{5}$, era o fundamento e sintetizava o essencial da religião HBS. Pois, em todos os momentos presenciados (cultos diversos, limpeza do altar, passeata, etc.), os sacerdotes buscavam expandir tal expressão ritual para o maior número de pessoas possível (sejam elas devotas ou leigas), através da pronúncia quase incessante deste mantra.

Ao delimitar o Namumyouhourenguekyou como cerne da doutrina e, consequentemente, da minha pesquisa, me dediquei a uma análise mais detalhada e pormenorizada do material coletado. Para tanto, elaborei 58 pranchas verbo-visuais, seguindo os passos dos antropólogos Gregory Bateson e Margaret Mead, no célebre livro Balinese character: a photographic analysis ${ }^{6}$ (1942).

\footnotetext{
${ }^{3}$ Disponível em http://www.culturaebarbarie.org/sopro/outros/atlas.html.

${ }^{4} \mathrm{Na}$ verdade, não existem fotografias idênticas. Aqui, o termo "repetidas" faz referência à imagens semelhantes. O critério de escolha também foi técnico-estético. A melhor imagem, seguindo este critério, foi escolhida, em detrimento das demais.

5 As cinco sílabas (Myou-hou-ren-gue-kyou) não representam uma escrita nem um significado, mas o espírito completo de Buda. São os Três Mil Mundos inerentes ao devoto. É a natureza búdica de todos os seres. Todo o ato, a fala e o silêncio dos seres se originam de um só sentimento. Portanto, ao serenar seus sentimentos, sem hesitação, detendo-se unicamente ao Myouhou, não se perderá no ciclo de vida e morte, a lealdade ao soberano e o amor filial serão verdadeiros - em http://www.budismo.com.br/doutrina1.php.

${ }^{6}$ Este livro mostra os resultados da imersão de Gregory Bateson e Margaret Mead junto aos habitantes da ilha de Bali. Em suma, são 100 páginas duplas (pranchas verbo-visuais) compostas por sequências de
} 
Após elaborar estas pranchas, as apresentei para a comunidade HBS e, de acordo com o feedback recebido pela criteriosa análise e contribuição dos sacerdotes, fiz as devidas alterações no conteúdo verbo-visual, para melhor representar o cotidiano dos clérigos.

Entretanto, ao término da pesquisa de mestrado, percebi que o material coletado não foi utilizado em todas as suas potencialidades. De fato, este registro teve um papel documental, no qual as fotografias foram, normalmente, ilustrações de uma legenda descritiva, que nem sempre abordavam toda a complexidade dos rituais religiosos e das atividades cotidianas presenciadas.

\section{Um tema: Antropologia, fotografia e ritual}

A escolha de uma corrente específica do Budismo para desenvolver esta pesquisa - a Honmon Butsuryu-shu - se faz necessária tendo em vista a grande quantidade de monastérios e correntes budistas existentes no Brasil e no mundo. Como seria inviável realizar uma pesquisa de campo satisfatória em todos os monastérios existentes no país, a Catedral Nikkyoji foi escolhida por causa da sua localização mais acessível (próximo de Campinas) e por pertencer à tradição Mahayana ${ }^{7}$.

Neste sentido, torna-se fundamental situar o contexto histórico/mitológico do Budismo em geral e o da HBS, especificamente. Para tanto, é necessário entender que todas as correntes budistas tem como ponto em comum a crença no Buda Histórico (que nasceu em Lumbini, no Nepal, com o nome de Siddharta Gautama), fundador do Budismo. Após a morte do Buda, que peregrinou e pregou por cerca de 50 anos pelo sub-continente indiano, o Budismo se expandiu, passando pela Índia e pela China, até chegar ao Japão. Após este período, houve um cisma que culminou nas duas grandes vertentes budistas, Mahayana e Theravada. Enquanto a tradição Theravada ${ }^{8}$ defende que "o Budismo é uma tarefa de tempo integral", onde a libertação está destinada apenas aos monges, a corrente Mahayana nos diz que a libertação pode ser alcançada “tanto por leigos quanto por monges e monjas" (Smith e Novak, 2003, p. 69).

fotografias realizadas por Bateson, de um lado, e comentários e relatos textuais (referentes à mesma série de imagens) escritos por Mead, do outro.

${ }^{7}$ Maha significa grande $e$ yana significa balsa ou barco. A alusão à figura de um grande barco transmite a ideia central desta vertente budista: De que todos os seres vivos podem alcançar a salvação, atravessando o rio da morte no grande barco da corrente Mahayana.

${ }^{8}$ Significa "O Caminho dos Anciões". 
Esta concepção distinta entre as duas tradições faz com que o Budismo Mahayana em geral, e o da HBS, especificamente, mostre-se mais aberto à visitação do público, permitindo que ele participe dos seus rituais (no caso, todas as cerimônias que envolvem a emanação da oração sagrada, Namumyouhourenguekyou), além de oferecer, no Brasil, palestras e cultos na língua portuguesa, o que facilita o acesso à esta tradição budista, tornando possível e viável minha pesquisa de campo.

Aqui, é fundamental destacar que a Honmon Butsuryu-shu consiste em uma corrente com importantes diferenças em relação às outras correntes budistas. Suas atividades estão voltadas para a prática da fé através das cerimônias rituais, sendo que a meditação, muito valorizada nos demais segmentos, recebe menor importância. Além disso, a HBS possui um líder religioso eleito trienalmente, que é chamado de sumopontífice (em português), ao contrário do lamaísmo, no qual os dalai-lamas são considerados os líderes religiosos e políticos (e quase divindades) e governam durante toda a vida. Outra distinção fundamental é que os membros da sangha ${ }^{9}$ da HBS não recebem nenhuma proibição, podendo consumir carne, bebidas e até mesmo se casar (inclusive os sacerdotes, que moram com suas famílias nos templos da HBS).

Ricardo Mário Gonçalves, por exemplo, nos mostra em seu livro A ética Budista e o espírito econômico do Japão (2007), a principal obra de Suzuki Shôsan, um grande mestre do Zen-budismo (que também consiste em uma corrente japonesa do Budismo Mahayana), que a vida laica (ou leiga) passou a ser cada vez mais valorizada no Budismo japonês a partir do século XV, como uma opção tão viável quanto a vida monástica para alcançar a realização espiritual (2007, p. 49).

É preciso ressaltar, ainda, uma importante distinção budista da HBS. Nesta tradição há uma intenção evidente em mostrar a existência do que eles chamam de Budismo Primordial. Para os devotos desta corrente, existe um Buda Primordial, primeiro, que é a origem de todos os Budas e princípio também de toda e qualquer forma de existência.

O Budismo HBS coloca, portanto, o Buda Primordial como uma espécie de divindade máxima, criadora, diferentemente das demais doutrinas budistas, que são ateias em relação a uma entidade suprema. Tal Buda Primordial teria transmitido (através do Buda Histórico) o chamado Sutra Lótus Primordial ou Sutra do Lótus da Lei Excelente, que é totalmente sintetizado pela escritura sagrada

\footnotetext{
${ }^{9}$ Sangha é uma palavra em pali ou sânscrito, traduzida como "assembleia" ou "communidade".
} 
Namumyouhourenguekyou, presente em todos os altares da HBS. A respeito desta particularidade, Gonçalves nos diz que "Nichiren fulminava com a mais radical condenação todos os que não seguissem sua doutrina, baseada no SaddharmaPundarika-Sutra (Sutra do Lótus da Lei Excelente) e era, por sua vez, condenado por todas as escolas" (2007, p. 59).

De fato, ao acompanhar durante dois anos a comunidade HBS, notei que as diversas cerimônias realizadas, sejam elas cultos vespertinos e noturnos, cultos póstumos, orações fervorosas, visitas assistenciais e até mesmo momentos, a priori, profanos, (descontração dos sacerdotes e fiéis, refeições, brincadeiras, conversas informais, entre outros), tiveram como preceito básico a recitação do mantra e ritual sagrado Namumyouhourenguekyou.

Neste sentido, Victor Turner nos diz que “(...) uma coisa é observar as pessoas executando gestos estilizados e cantando canções enigmáticas que fazem parte da prática dos rituais, e outra é tentar alcançar a adequada compreensão do que os movimentos e as palavras significam para elas" (1974, p. 20).

Debruçar sobre o ritual de emanação deste mantra permite também, como sugere Turner, entender como:

Os rituais revelam os valores no seu nível mais profundo e os homens expressam no ritual aquilo que os toca mais intensamente e, sendo a forma de expressão convencional e obrigatória, os valores do grupo é que são revelados. Vejo no estudo dos ritos a chave para compreender-se a constituição essencial das sociedades humanas (1974, p. 19).

De fato, Turner "toma o ritual como drama, e o drama (as crises políticas, sociais e de vida) como ritual, inventando um modo original e promissor de penetrar na vida de uma sociedade" (1967, p. 25-26). Além disso, o antropólogo britânico foi um estudioso obcecado pelas formas rituais e o "criador de uma antropologia do drama e do ritual, levando os postulados de Arnold Van Gennep aos seus limites" (1967, p. 26).

(...) o que propunha era um programa de análise no qual a vida ritual deveria ser vista como um mecanismo privilegiado de sublimação de valores negativos e/ou reprimidos que eles revelavam e traziam à tona por meio de gestos bizarros e objetos especiais - um conjunto de 'símbolos' interligados, verdadeiros caminhos ou sendas - que, vistos em conjunto, formavam um tecido móvel, vivo e dinâmico: uma floresta cuja exploração transformava (1967, p. 26). 
Assim, o autor traz à tona os conceitos de ritual e símbolo, essenciais para a análise das diversas cerimônias da Honmon Butsuryu-shu ${ }^{10}$, tendo como principal alicerce a recitação do mantra sagrado.

\begin{abstract}
Por 'ritual', entendo o comportamento formal prescrito para ocasiões não devotadas à rotina tecnológica, tendo como referência a crença em seres ou poderes místicos. $\mathrm{O}$ símbolo é a menor unidade do ritual que ainda mantém as propriedades específicas do comportamento ritual; é a unidade última de estrutura específica em um contexto ritual. (...) um símbolo é uma coisa encarada pelo consenso geral como tipificando ou representando ou lembrando algo através da posse de qualidades análogas ou por meio de associações em fatos ou pensamentos. Os símbolos que observei em campo eram, empiricamente, objetos, atividades, relações, eventos, gestos e unidades espaciais em uma situação ritual (1967, p. 49).
\end{abstract}

Além destas definições, Turner (1967) também colabora ao levantar uma questão capitular para o presente trabalho. O autor nos diz que a estrutura e as propriedades dos símbolos rituais são deduzidas de três tipos de dados: “(1) forma externa e características observáveis; (2) interpretações dadas por especialistas e leigos; (3) contextos significativos amplamente elaborados pelo antropólogo" (1967, p. 50). As três formas de análise dos dados etnográficos elencadas por Turner serão, aqui, potencializadas com o auxílio das fotografias, que podem contribuir como prova material para a análise das características externas, sem que o etnógrafo tenha que retornar inúmeras vezes para o campo (pois ele possuirá o registro visual dos rituais por ele analisados); como instrumento de análise ritual para a própria comunidade (sacerdotes e fiéis) estudada (que poderá retomar as fotografias e realizar uma análise pormenorizada das cerimônias) e como meio de rememoração para o próprio pesquisador, que através das fotografias poderá retomar os rituais e cunhar, com cautela e o tempo necessário, suas hipóteses sobre o contexto ritual presenciado.

De fato, ao acompanhar o cotidiano sagrado e profano deste segmento budista, tanto no Brasil quanto no Japão, uma outra capitular questão surgiu através da análise das cerimônias realizadas pela HBS em contextos socioculturais tão distintos. Através das duas fases de pesquisa de campo aqui relatadas, foi possível perceber, minuciosamente, como uma expressão religiosa oriental realiza um processo de adaptação e aceitação sociocultural no contexto brasileiro.

\footnotetext{
${ }^{10}$ Existe uma ampla gama de rituais na HBS, incluindo rituais de passagem ou de crise de vida como cultos póstumos, batizados, casamentos, nomeações sacerdotais, entre outros.
} 
A primeira observação, neste quesito, é o surgimento de expressões provenientes de um vocabulário ocidentalizado, como "ascese", "arcebispo", "sumo-pontífice", "catedral", "Papa" e "Deus", notadamente utilizados pelos religiosos e fiéis da HBS do Brasil, mas que não possuem correspondência direta com as expressões em japonês. Este vocabulário surpreende, pois utiliza termos de uma tradição muito assimilada pelo cristianismo, apropriada por uma religião oriental, o que significa uma série de adaptações, traduções e incorporação de um vocabulário.

Neste sentido, podemos estender as definições de Ana Cristina Lopes Nina (2006) que, embora trabalhe especificamente com o Budismo Tibetano e o seu contexto de diáspora pelo mundo, pode servir, aqui, como alicerce teórico para compreender as adaptações e reformulações encontradas na HBS do Brasil para se encaixar no contexto sociocultural brasileiro (tão distinto do japonês) e conquistar novos adeptos. Segundo a autora:

\begin{abstract}
... fora de seu contexto original, qualquer cultura se transforma, antes de mais nada, em instrumento que possibilita a comunicação, e por isso é preciso levar em conta o que se tornará significativo no(s) novo(s) contexto(s) em que se verá inserida. Para que uma cultura desempenhe com sucesso tal tarefa, é necessário selecionar, no seu interior, esses elementos significativos que tornam possível a comunicação. No caso da cultura tibetana na diáspora, parece possível dizer que, nesse processo de seleção, foi precisamente o budismo que, por um processo de "condensação", passou a significar, no plano político assim como em termos espirituais, uma espécie de súmula da cultura tibetana, sua face mais visível ou aparentemente de mais fácil acesso, transformando-se na principal moeda de negociação, para os tibetanos, do seu lugar frente às sociedades ocidentais nas quais se viram inseridos. Em outras palavras, o budismo tibetano passou a constituir na diáspora, para os tibetanos e para o mundo, um traço diacrítico, definidor de identidade. Na diáspora, no entanto, não seria possível falar em uma única identidade. Em um certo sentido, a inserção no mundo moderno fez muito mais do que simplesmente colocar o budismo tibetano diante de um novo contexto. Na verdade, seu principal efeito foi trazer algumas das lógicas inerentes à modernidade, e mais especificamente a tendência à fragmentação e ao "confronto" com outras realidades culturais, para o cerne do budismo tibetano. Interessa-me aqui, portanto, o movimento de transformação necessariamente provocado por esses novos elementos que permeiam o budismo tibetano (2006, p. $31-32)$.
\end{abstract}

Por fim, o presente trabalho também coloca a questão da fotografia como registro e também como um ritual moderno, que envolve diversos personagens como o fotógrafo, a comunidade fotografada (que realiza uma performance diante da câmera) e os espectadores das imagens. Neste caso, o intuito é compreender como se dá, em primeiro plano, a aceitação de um fotógrafo/antropólogo outsider em uma comunidade, até o ponto deste observador ser incorporado e aceito como fotógrafo oficial dos principais rituais da religião no Brasil, mesmo sem ter sido convertido. Podemos, ainda, 
considerar o ato (ritualizado) de olhar para um álbum de fotografias, seja impresso ou virtual/digital, e rememorar os acontecimentos como se as fotografias tivessem o poder mágico de revitalizar o tempo, o espaço e os personagens envolvidos na trama fotográfica.

De acordo com Roberto Da Matta, no prefácio à obra Os ritos de passagem (Van Gennep, 1978):

O rito, assim, também enquadra - na sua coerência cênica grandiosa ou medíocre aquilo que está aquém e além da repetição das coisas reais e concretas do mundo rotineiro. Pois o rito igualmente sugere e insinua a esperança de todos os homens na sua inesgotável vontade de passar e ficar, de esconder e mostrar, de controlar e libertar, nesta constante transformação do mundo e de si mesmo que está inscrita no verbo viver em sociedade (11).

Deste ponto de vista, seria possível pensar em uma relação direta entre fotografia e o rito, na qual a primeira consiste, também, em um novo tipo de ritual, já que a fotografia compartilha com os ritos tradicionais estas mesmas características (“inesgotável vontade de passar e ficar, de esconder e mostrar, de controlar e libertar").

\section{Caminho Primordial}

Neste sentido, o intuito deste artigo é mostrar, também, que nosso conjunto de fotografias, aliadas aos relatos orais e registros verbais coletados (diário de campo), é capaz de traçar, retratar e reconstruir o dia a dia (profano/sagrado e, sobretudo, ritual) das atividades (internas e externas) de uma sociedade religiosa budista. Sociedade esta organizada e hierarquizada - que, no contexto japonês/brasileiro, representa uma das vertentes mais puras da religião.

Desta forma, o substrato apresentado a seguir, composto de imagens e relatos orais, teve origem em uma viagem ao Japão (visitando os templos da HBS), Nepal e Índia (que correspondem aos locais de origem e expansão do Budismo, antes da expansão para o Tibete e, posteriormente, ao Japão), a convite do Arcebispo Kyouhaku Correia, principal autoridade da religião no Brasil.

Nesta viagem, acompanhei uma caravana da HBS, convivendo com trinta e seis (36) fiéis e quatro (04) sacerdotes brasileiros, além da comunidade religiosa encontrada nos templos nipônicos. 
Perpassando esta etapa de pesquisa de campo, a constatação a ser verificada é de que o material coletado (imagens, entrevistas e diário de campo) oferece as condições de poder pensar este registro verbo-visual como um alicerce material e ritualizado (já que envolve uma interação entre observador, observados, espectadores das imagens, temporalidades e relações espaciais distintas), fundamental para a observação e identificação do campo e do contexto ritual e para a percepção e análise simbólica das práticas religiosas da comunidade HBS.

Aqui, seguimos os pressupostos de Silva (1991), quando este nos diz que as produções etnográficas pós-modernas se transformam em fontes legítimas de consulta para os leitores religiosos, "que passam a tratar as informações etnográficas como verdadeiros estatutos de regras rituais" (1991, p. 47).

Assim, observando os observadores e seus escritos (antropólogos em sua prática de pesquisa), as preocupações destes etnógrafos (ou "meta-etnógrafos") recaíram sobre questões relativas ao próprio processo de produção do conhecimento antropológico e sobre a autoria dos textos resultantes desse processo (Silva, 1991, p. 49).

Assim, pretendo estabelecer o conhecimento etnográfico adquirido como resultado de situações de diálogo entre subjetividades concretas, que interagem em condições sobredeterminadas de contato e de negociação de sentido. Ou seja, o trabalho busca privilegiar não somente a voz do antropólogo, culminando em um texto o mais polifônico possível. Neste sentido, Clifford nos diz:

"Um modelo discursivo da prática etnográfica dá preeminência à intersubjetividade de toda fala, e ao seu contexto performativo imediato...; as palavras da escrita etnográfica... não podem ser construídas monologicamente, como uma afirmação de autoridades sobre, ou interpretação de uma realidade abstrata, textualizada. A linguagem da etnografia é impregnada de outras subjetividades e de tonalidades contextualmente específicas. Porque toda linguagem na visão de Bakhtin, é uma concreta concepção heteróglota do mundo". (Clifford, 1983: 133, trad. Tereza Caldeira).

\section{Pequenas Histórias}

Desde o meu primeiro contato com a HBS do Brasil, no início de 2011, percebi que existia um informante privilegiado que, guardada as devidas proporções, desempenhou um papel semelhante ao de Muchona ("A Vespa"), de Victor Turner (1967). 
Trata-se do já citado Arcebispo Kyouhaku Correia ${ }^{11}$, sacerdote superior da HBS e principal autoridade religiosa. Além de deter este poder religioso, tal sacerdote também era o coordenador da caravana, intérprete (dominando bem o idioma japonês, falado não apenas no Japão mas, também, pelos nossos guias na Índia e no Nepal) e principal conhecedor da cultura oriental e da doutrina budista, tendo formação em teologia no Japão.

Tal clérigo foi, desde o início, o principal responsável pela realização da pesquisa, sendo, aliás, o grande estimulador da minha viagem junto com a caravana, acordada para ser realizada desde o final de 2012.

Aqui, porém, é fundamental mostrar o desenvolvimento da relação entre antropólogo/fotógrafo e a comunidade estudada. Apesar de ter sido bem recebido desde minha primeira visita de campo (pela minha descendência nipônica e por ter parentes que pertencem a religião), a relação com a comunidade HBS nem sempre foi de total cordialidade. Já na primeira reunião presenciada (e gravada) em maio de 2011, que tratava de assuntos burocráticos e financeiros, o arcebispo Correia chamou minha atenção, dizendo:

Alex, quero que você preste atenção na reunião e pare de fotografar um pouquinho. Não adianta fotografar tudo e não entender o que está vendo. Você vai ter muito tempo para fotografar depois, mas agora é hora de ouvir (Kyouhaku Correia, arcebispo da HBS, 2011).

Este evento não ocorreu isoladamente. Por diversas vezes a inexperiência me causou embaraço no estabelecimento da minha relação com esta comunidade. Em outra ocasião, também na Catedral Nikkyoji, quando fotografava com uma tele-objetiva (lente capaz de aumentar o zoom), uma senhora japonesa pediu ao sacerdote Kyougyou Amaral para chamar minha atenção, pois sentia-se incomodada.

Em contraste com o fato ocorrido, após exatos três anos de pesquisa e intenso convívio com a comunidade, na véspera da viagem e durante todo o percurso da caravana, o arcebispo Correia fez questão de me colocar no lugar legitimado de fotógrafo oficial. Assim, me apresentou ao grupo (do qual boa parte dos integrantes já eram conhecidos) de sacerdotes e fiéis como "Elias" (meu último sobrenome, que constava no meu passaporte):

\footnotetext{
${ }^{11}$ No final de 2014, o sacerdote superior e arcebispo da HBS do Brasil, Kyouhaku Correia, foi elevado ao grau de pré-pontífice, passando a se chamar Nitinyuu Correia.
} 
Durante toda a viagem o fotógrafo oficial é o Elias. Ele é o nosso fotógrafo oficial. Lá no Japão e na Índia e no Nepal vai ter um monte de gente fotografando. Porque o pessoal é japonês né? Japonês gosta de tirar foto. Mas todo mundo vai olhar para o Elias primeiro, esperar que ele tire uma ou duas fotos e daí olha pras outras máquinas. Assim todo mundo vai ter uma foto de lembrança de cada lugar que a gente passou (Kyouhaku Correia, arcebispo da HBS, 2014).

Neste sentido, tendo o arcebispo Correia como informante e tradutor principal, mostro e relato - a partir de fotografias e de registros verbais coletados nos exatos locais dos mitos -, pequenos (e importantes) mitos e acontecimentos que foram narrados por sacerdotes e fiéis no Japão e contados pelos guias locais, na Índia e no Nepal, capazes de demonstrar algumas nuances da complexa relação estabelecida/conquistada em campo e sempre tendo como foco principal o ritual de emanação do mantra (e imagem) sagrado, Namumyouhourenguekyou.

\section{Mito do nascimento do Buda Histórico}

Apesar do Budismo HBS ser repleto de particularidades, seu mito inicial condiz com o das demais correntes e segmentos. De fato, a religião nasceu no Nepal (que, há 2.500 anos atrás, pertencia ao subcontinente indiano), em uma cidade chamada Lumbini, que fica bem ao sul do país, próximo da divisa com a Índia.

Neste contexto, diz o mito que uma mulher chamada Mayadevi (ou apenas Maya, em outros relatos), casada com o rei (ou, melhor dizendo, uma espécie de senhor feudal) Suddhodana, regressava para sua terra natal para dar à luz a um menino.

Este menino se tornaria, 29 anos depois, "O Iluminado", o ser que conseguiria eliminar todo o karma $^{12}$ e sair do ciclo, quase interminável, do sansara ${ }^{13}$.

O "Buda Menino", como é chamada a suntuosa estátua que fica localizada próxima ao local exato do nascimento do garoto, mostra a natureza quase divina de Siddharta Gautama.

\footnotetext{
${ }^{12} \mathrm{O}$ karma consiste em um princípio básico do Budismo, provavelmente herdado do Hinduísmo, religião predominante na Índia durante a vida do Buda Histórico. Este conceito nos diz que todo pensamento ou prática trará um karma, que pode ser negativo, positivo ou neutro. Assim, para sair do ciclo quase interminável de nascimento e morte (chamado sansara), todo karma negativo e positivo deve ser extinto. Tal conceito também é utilizado em outras religiões, como o espiritismo kardecista.

${ }^{13}$ Ciclo quase interminável de nascimento e morte, gerado pelo karma.
} 
Nas palavras do arcebispo Correia:

Este aqui é o Buda Menino. A história do Budismo fala que o menino que ia ser o Buda Histórico ou Buda Shakyamuni nasceu aqui no Nepal, nessa região chamada Lumbini, exatamente aqui. Esta estátua mostra a natureza pura e iluminada dele. Assim que ele nasceu já deu sete passos e embaixo de cada passo apareceu uma flor de Lótus, que é um símbolo sagrado do Budismo. Porque a flor de Lótus representa pureza. Ela nasce na lama, na sujeira, depois passa pela água, se purificando e chega ao ar livre. Além disso, ele nasceu das axilas da mãe, porque na época diziam que as pessoas nasciam de partes do corpo que correspondiam à classe social ou aos clãs. Como o Buda era um guerreiro, de uma família guerreira, ele nasceu das axilas. Se fosse um brâmane, da classe religiosa da Índia, teria nascido da cabeça. Se fosse pobre, ele teria nascido das partes inferiores e até do pé. Ele também falou imediatamente após o nascimento e só depois voltou a ser uma criança normal. Por isso, essa é a única estátua que nós da HBS podemos levar para casa. Por causa dessa natureza pura do Buda Menino (Kyouhaku Correia, arcebispo da HBS, 2014).

Esta fala final do Arcebispo vai de encontro com um dos momentos no qual ele me repreendeu (apenas com um olhar de reprovação) por ter adquirido uma estátua do Buda Histórico na Índia, que levei como recordação da viagem. Como ele afirmou, a única estátua ou imagem que podem adorar, além da escritura/imagem sagrada Namumyouhourenguekyou, é a estátua do Buda Menino.

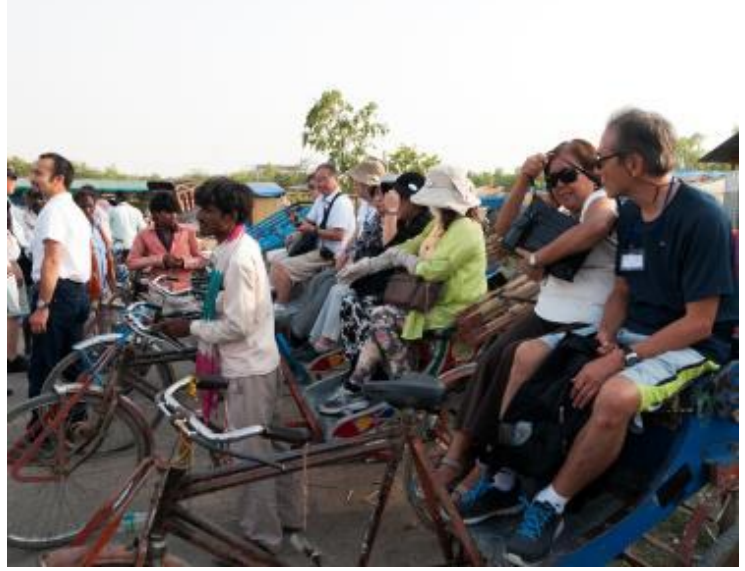

Foto 1: Fiéis e sacerdotes pegam carona em bicicletas para chegar ao local do nascimento do Buda Histórico.

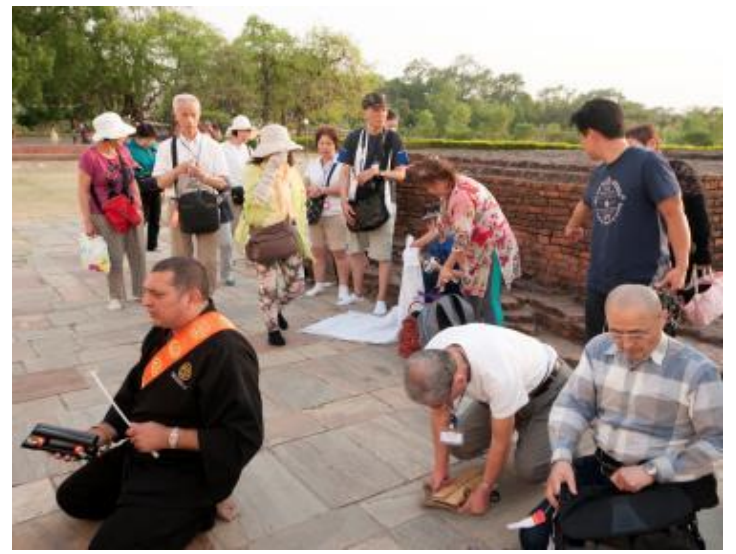

Foto 2: Comunidade HBS realiza um culto no local de nascimento do Buda Menino. Todos entoam o Namumyouhourenguekyou. 


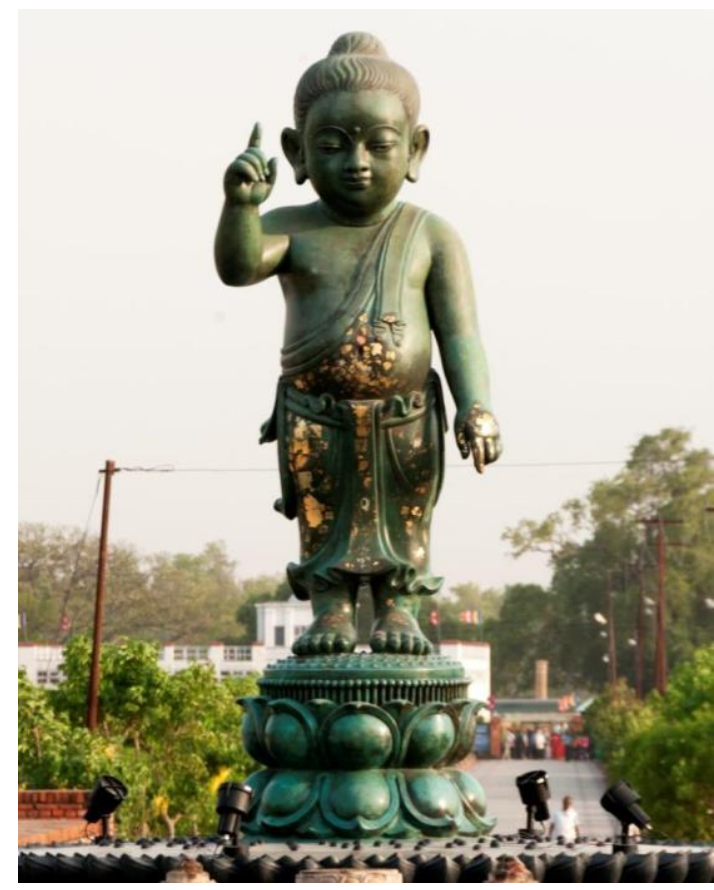

Foto 3: Estátua do Buda Menino, na cidade de Lumbini, Nepal.

\section{Reino do Buda}

Segundo a nossa história, Siddharta Gautama era filho de um senhor feudal, muito rico e poderoso, pertencendo à um importante clã de guerreiros chamado Shakya, que originou seu nome após atingir a Iluminação. Ele, que seria chamado de Buda Shakyamuni (ou Buda Histórico), vivia com seus pais em uma cidade ao norte da Índia, chamada Kapilvastu.

Foi neste mesmo lugar, hoje formado por ruínas que foram escavadas para possibilitar o turismo e a visitação ao local, que fui acometido por uma forte infecção alimentar, causada pelo intenso calor e a alimentação distinta. Este mesmo mal foi o responsável pela morte física do Buda, que contarei adiante. Nas palavras do arcebispo Correia:

O Buda também ficou muito doente, quando estava próximo de deixar a vida mundana e entrar de vez no Nirvana. Porque aqui faz um calor absurdo mesmo, $40^{\circ}$ de manhãzinha e a comida é apimentada e a água poluída. Aí você imagina que mesmo com o nosso ônibus, com água e ar-condicionado e 2.500 anos depois, com condições bem melhores de vida, todo mundo ficou doente, com infecção alimentar. Mas o Buda só deixou a vida física porque ele tinha cumprido o seu propósito, deixando para nós o Namumyouhourenguekyou (Kyouhaku Correia, arcebispo da HBS, 2014). 
Por hora, notamos que o Buda Histórico era um jovem rico e poderoso que, aos 19 anos de idade, percebendo a insensatez da existência que levava e a impossibilidade de escapar dos três males que afetavam a todos (doença, velhice e morte), renunciou à vida mundana para alcançar a Iluminação.

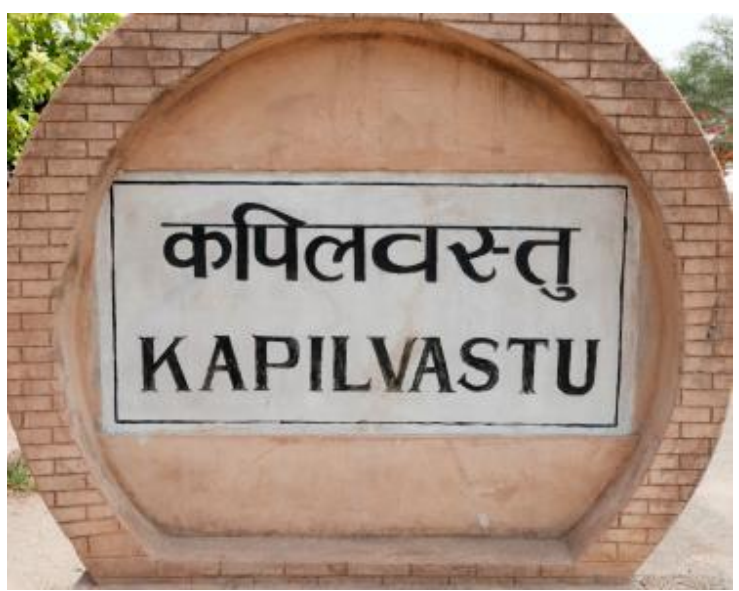

Foto 4: Entrada de Kapilvastu, local do antigo reino do Buda Histórico.

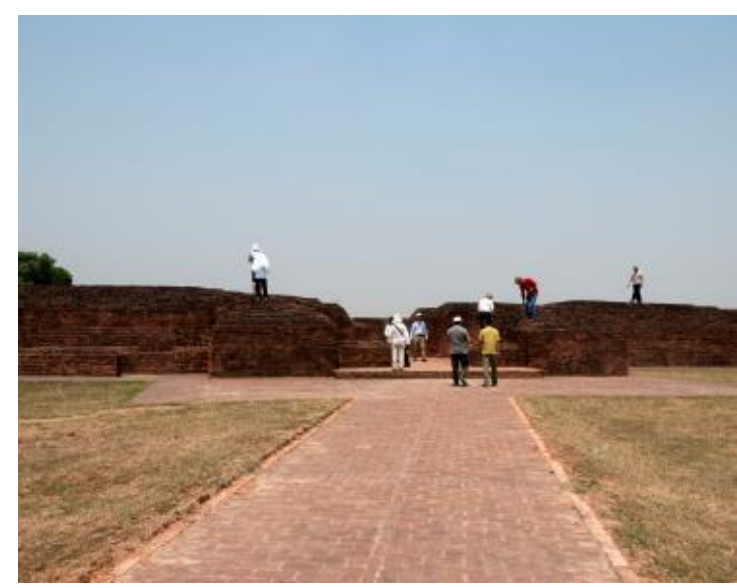

Foto 5: Local exato do reino do Buda Histórico, antes de atingir a Iluminação.

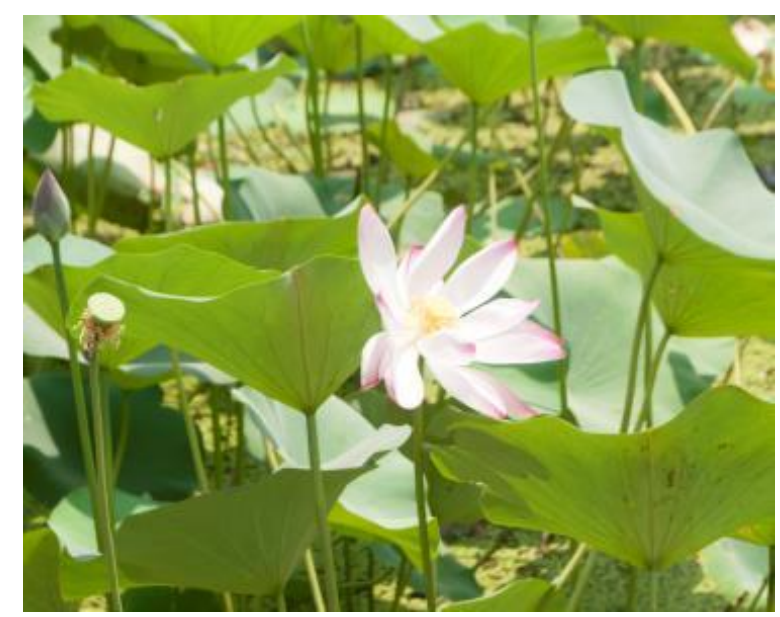

Foto 6: Flor de lótus em Kapilvastu. Esta flor é um símbolo clássico da religião, representando a natureza pura do Buda. 


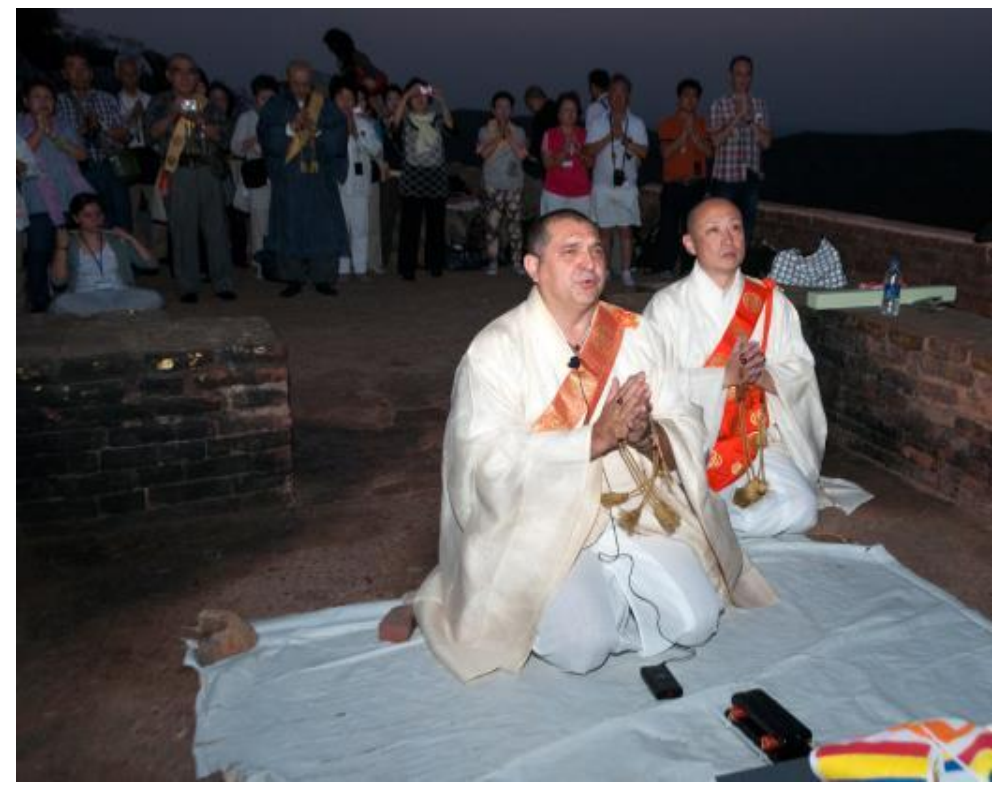

Foto 7: Pico da Águia, local onde o Buda recitou pela primeira vez o Mantra Sagrado que, traduzido do sânscrito antigo para o japonês significa Namumyouhourenguekyou.

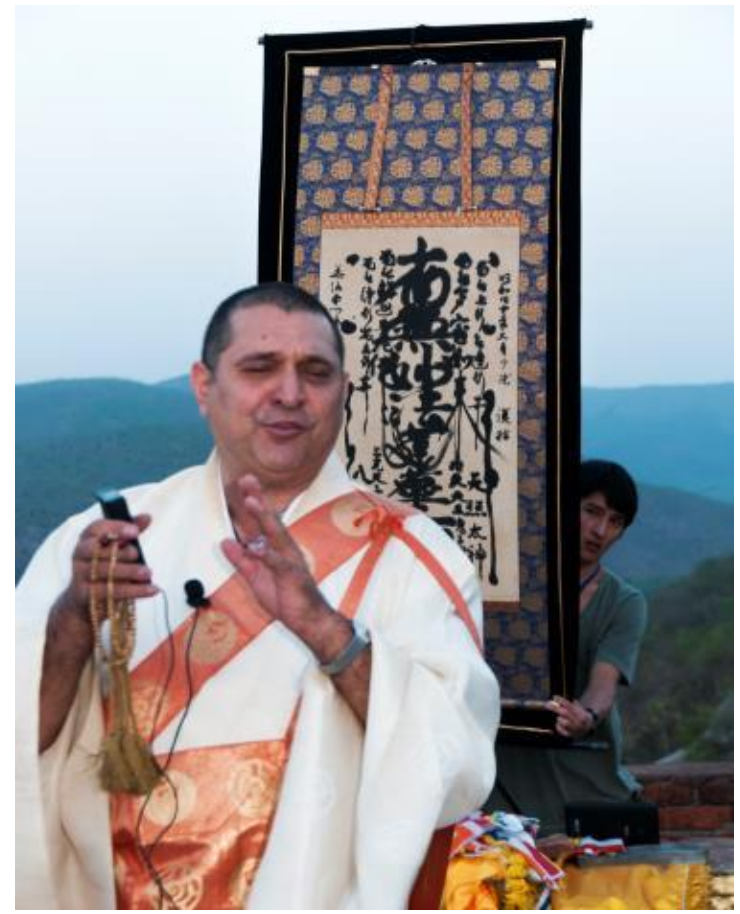

Foto 8: Pico da Águia. Arcebispo Correia passa ensinamentos. Ao fundo, a Imagem Sagrada Namumyouhourenguekyou. 


\section{Iluminação}

Após sair do seu palácio em Kapilvastu, peregrinar por dez anos e experimentar várias formas meditativas e práticas acéticas, Gautama chegou à cidade de Bodhgaya (na Índia), sentou-se sob uma árvore frondosa e decidiu que dali não sairia até atingir o Nirvana $^{14}$.

Este episódio é cercado por várias lendas e histórias. Segundo relatos dos guias locais, traduzidos pelo arcebispo Correia (nosso principal informante, interlocutor e profundo conhecedor da história indiana, da religião e da língua japonesa), durante o longo período de meditação, uma forte tempestade caiu e uma cobra naja gigantesca saiu de um lago e se postou sobre aquele que seria o "Iluminado", o protegendo da água até a chuva passar e, obviamente, sem atacá-lo.

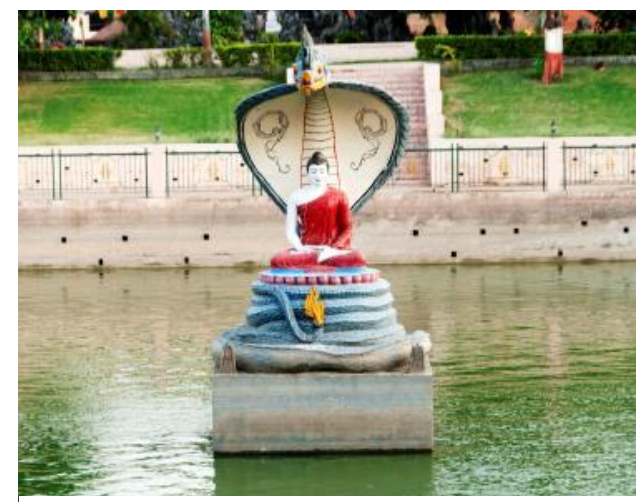

Foto 9: Estátua que representa a meditação de Siddharta Gautama, antes de atingir o Nirvana. Uma naja gigante o protege da chuva.

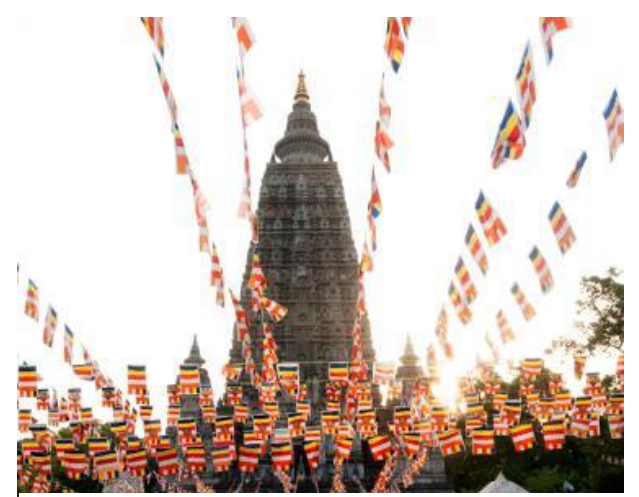

Foto 10: Monumento erguido no local onde ficava a árvore $B o$, sob a qual Siddharta Gautama atingiu o Nirvana. Ao redor, bandeiras do Budismo.

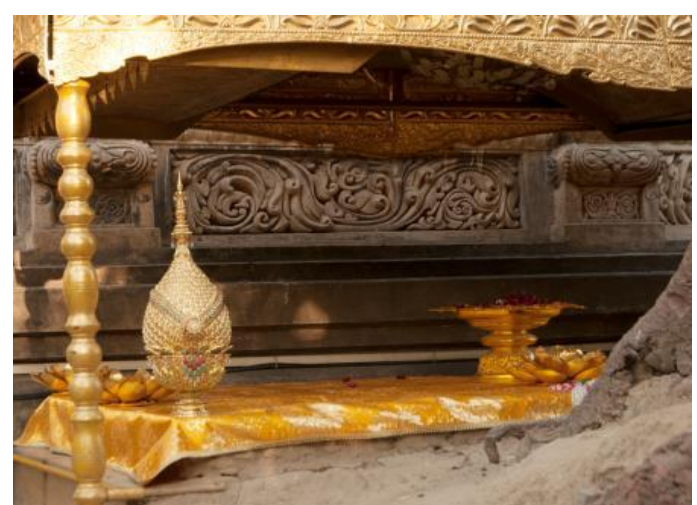

Foto 11: Segundo a tradição budista, este é o local exato onde Siddharta Gautama alcançou a Iluminação.

\footnotetext{
${ }^{14}$ Nirvana ou Iluminação é o objetivo máximo do Budismo. Ao atingir tal estado, o ser iluminado extingue todo karma e não mais passará pelo sansara, ciclo de nascimento e morte.
} 


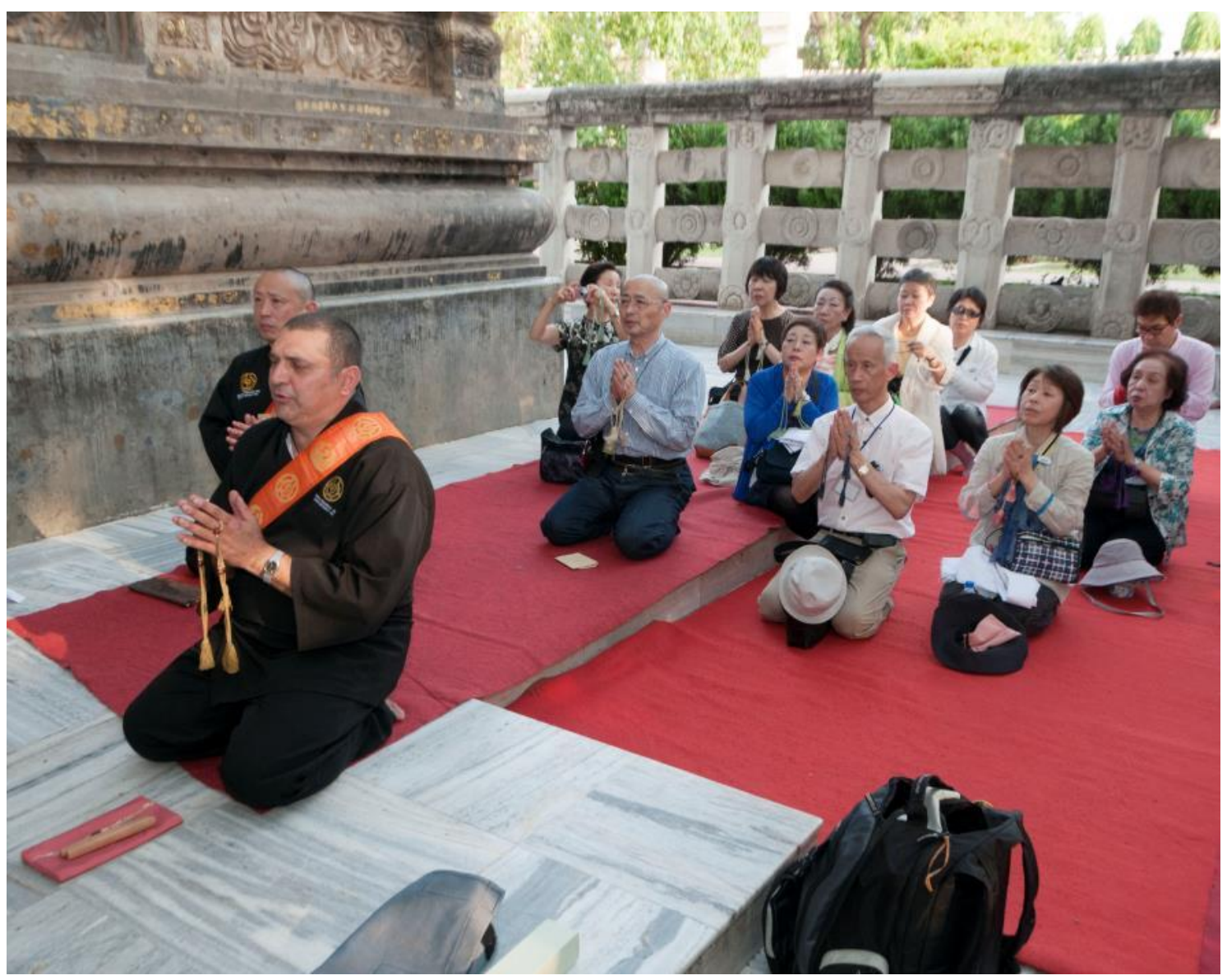

Foto 12: Culto realizado em frente ao local da Iluminação. Na frente temos o arcebispo Correia e, ao redor, outros sacerdotes e fiéis (brasileiros e japoneses). Todos oram o mantra sagrado, Namumyouhourenguekyou.

\section{Falecimento físico e restos do Buda}

Após peregrinar por quase 50 anos e instituir uma ordem monástica, o corpo físico do Buda Shakyamuni pereceu aos 80 anos de idade, na cidade de Kushinagar, na Índia.

Segundo livros e relatos ocidentais, o Buda teria morrido ao ingerir carne de javali, oferecida por Cunda, o ferreiro. Tal versão contradiz a dos religiosos da HBS e, também, de budistas indianos e nepaleses. Segundo eles, o Buda Histórico abandonou sua existência física propositalmente e entrou definitivamente no Nirvana ao ingerir (e se intoxicar com) uma sopa de cogumelos, oferecida pelo mesmo discípulo Cunda, já que, possivelmente, era vegetariano. 


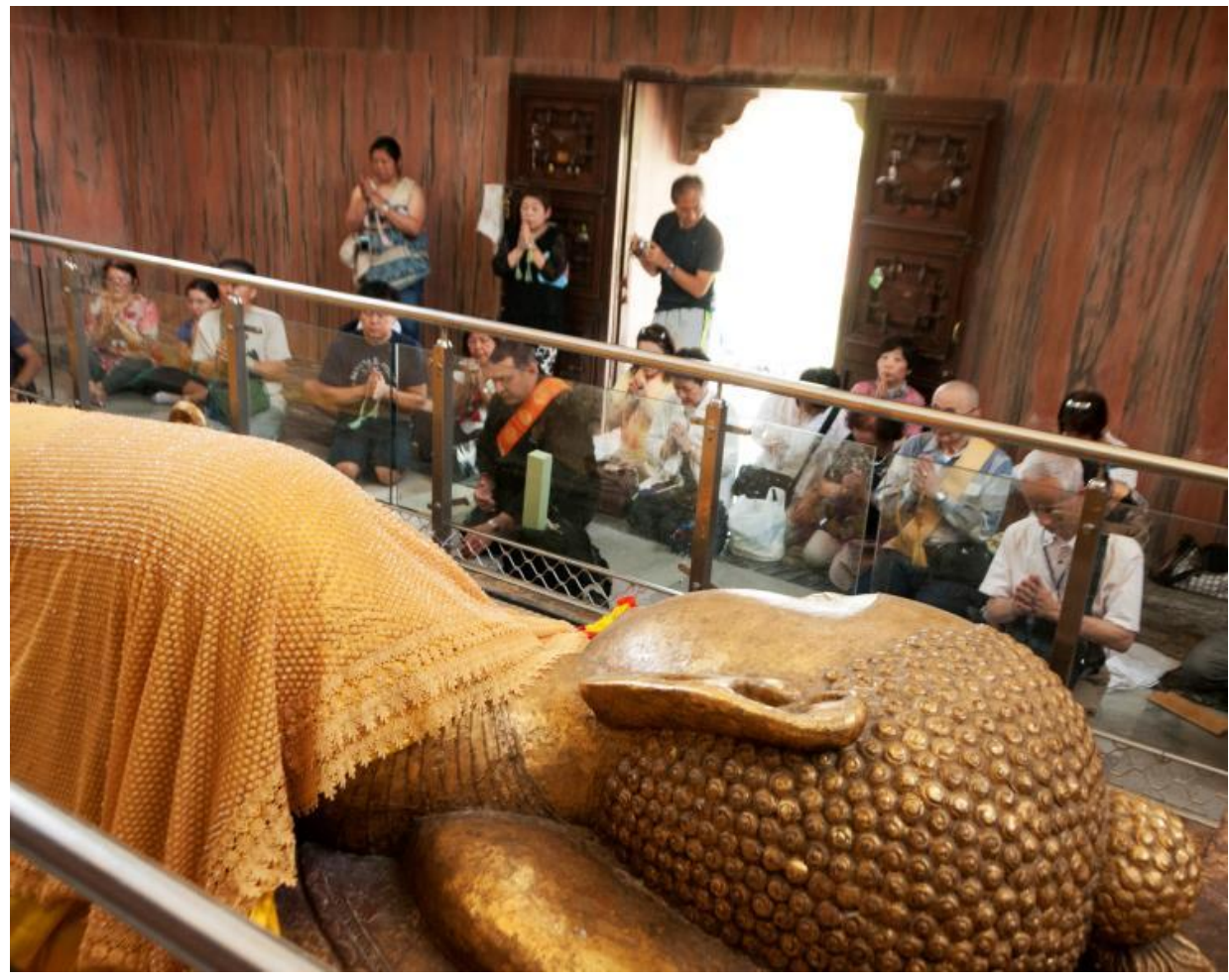

Foto 13: Comunidade HBS ora o Namumyouhourenguekyou, no local do falecimento físico do Buda.

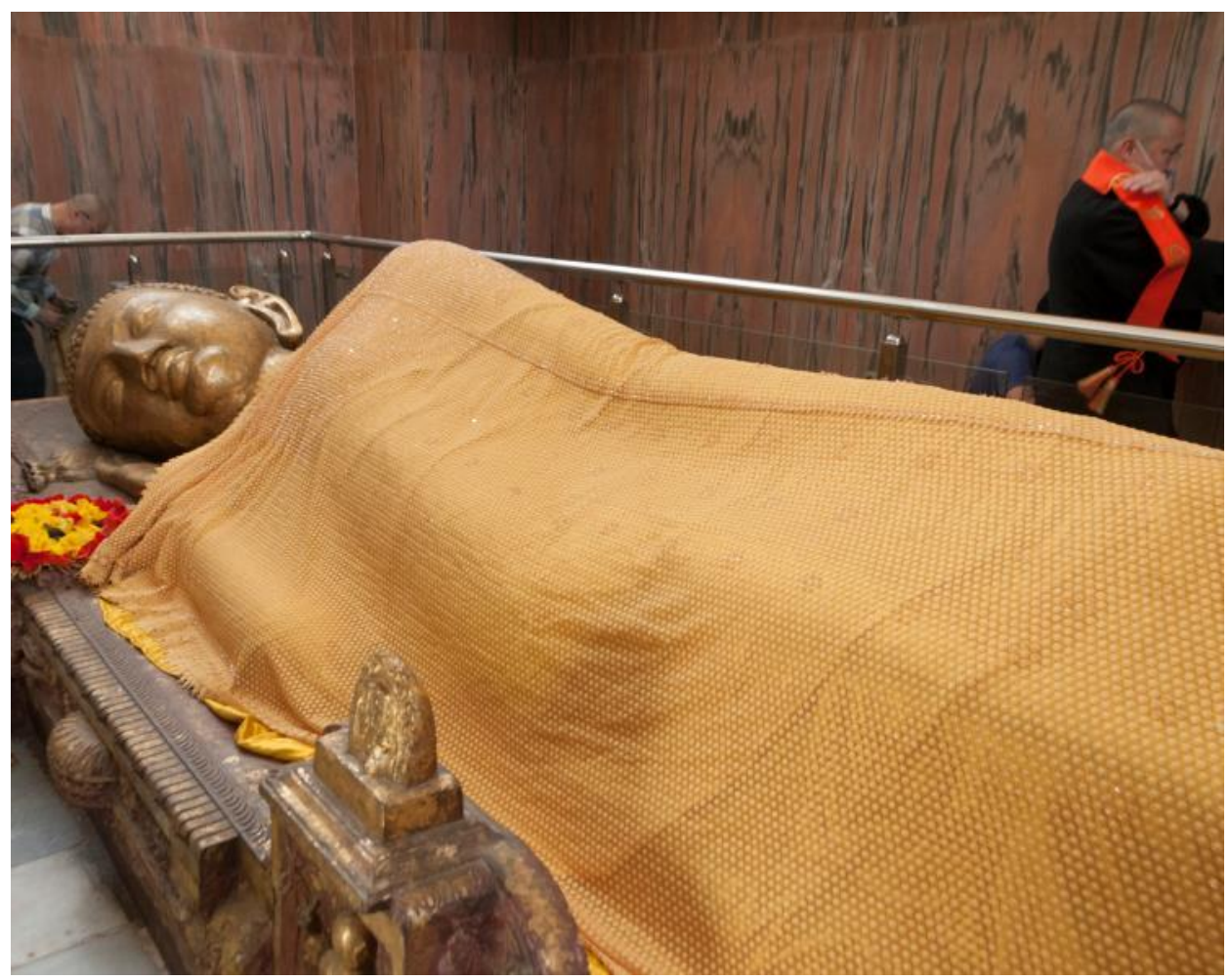

Foto 14: Estátua que representa o Buda, exatamente na posição do seu falecimento físico. 


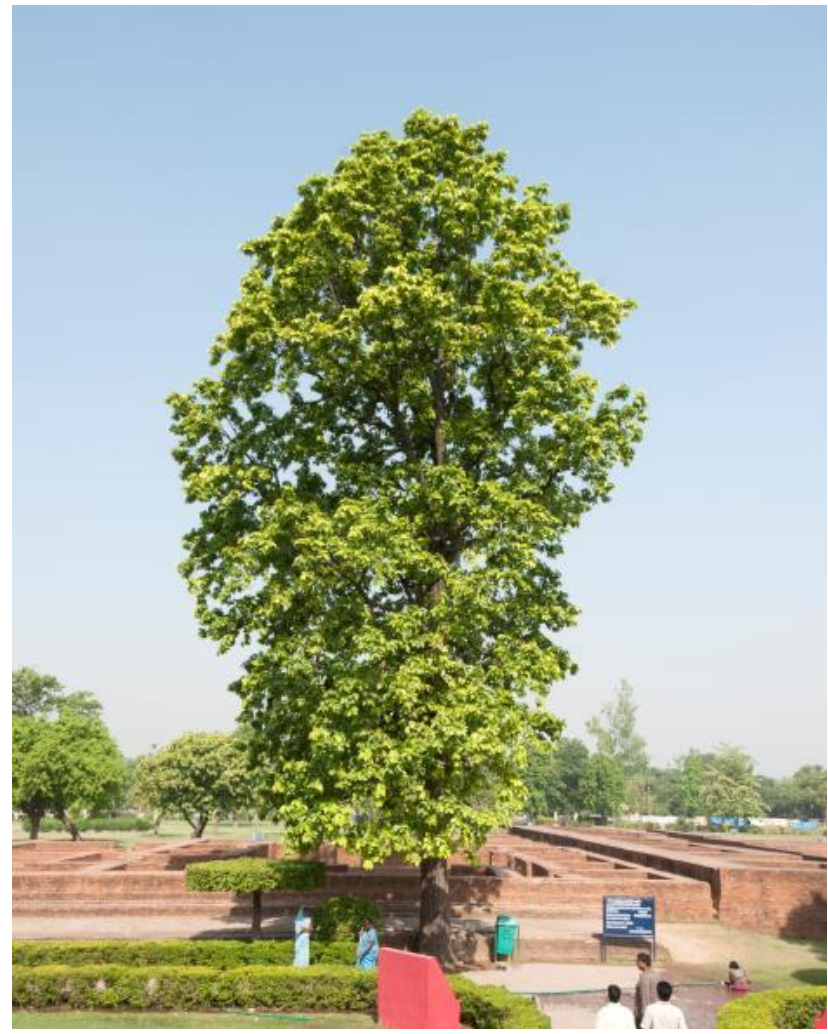

Foto 15: Um exemplar de árvore Bo. Segundo os relatos, foi debaixo desta mesma árvore que o Buda realizou seu último ensinamento ou Sutra. Ali, o Iluminado teria convertido seu último seguidor.

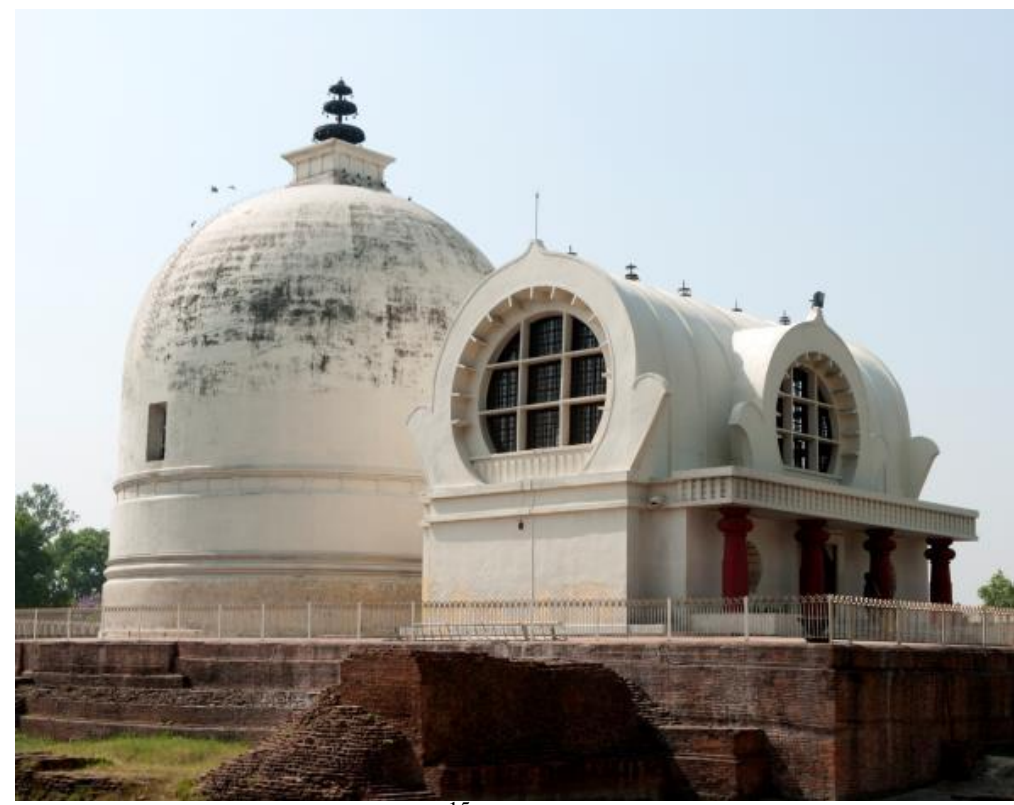

Foto 16: Vista geral da estupa ${ }^{15}$ onde o corpo físico do Buda pereceu.

\footnotetext{
${ }^{15}$ A estupa é um monumento construído sobre os restos mortais cremados de pessoas importantes e/ou em locais sagrados do Budismo.
} 


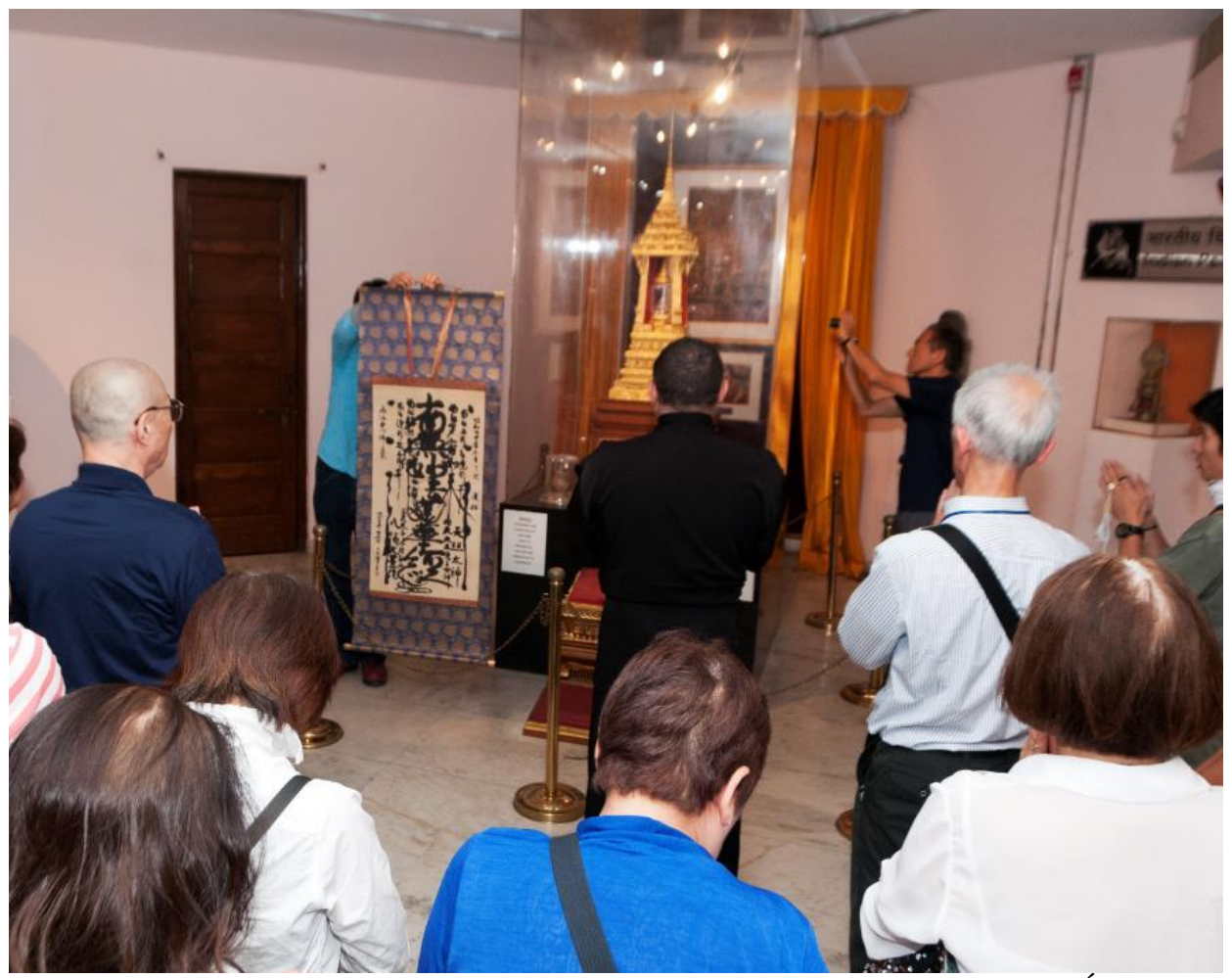

Foto 17: Interior do Museu Nacional Mahatma Gandhi, em Nova Delhi, Índia. Ao fundo, vemos a urna contendo os restos mortais do Buda, segundo os relatos dos guias locais, traduzidos pelo arcebispo Correia. Ao lado, vemos a imagem sagrada Namumyouhourenguekyou. Fiéis e sacerdotes fazem um culto, entoando o mantra sagrado.

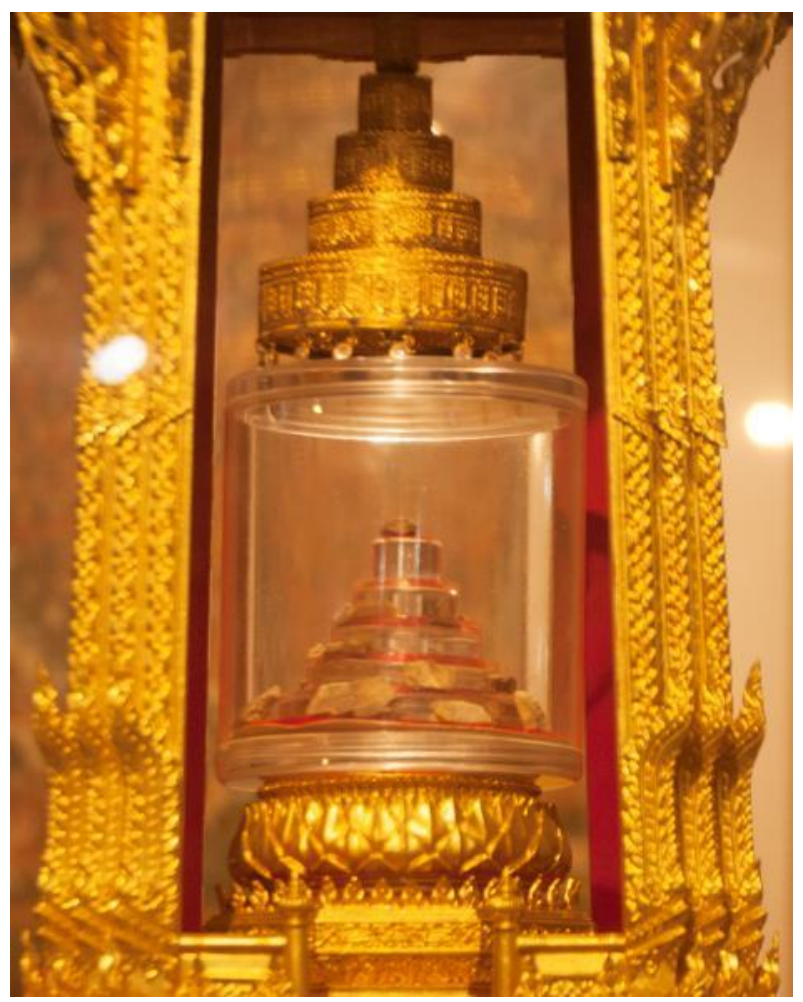

Foto 18: Urna contendo, segundo os relatos locais, os restos mortais do Buda. 


\section{História do Buda Amida}

Quando estávamos em Kamakura, cidade localizada na província de Kanagawa, na ilha de Honshu, visitamos o templo Kotoku-in, pertencente à corrente budista Jodoshu, distinta da HBS.

Tal religião é caracterizada por adorar o Buda Amida, considerado na mitologia budista geral como um dos cinco Budas da meditação. Neste templo em questão, temos um monumento fantástico do Buda Amida, feito de bronze no ano de 1.252, medindo cerca de 13,35 metros de altura e pesando 93 toneladas.

Apesar de ser uma construção fantástica, cartão postal da cidade (e também do país), a passagem da caravana no local não tinha muitos interesses religiosos (apenas turístico), afinal, a Honmon Butsuryu-shu não reverencia nem adora imagens de Budas.

Assim, realizei neste local um registro fotográfico, entre as madeiras do portão do templo, tentando captar a grandiosidade do monumento. Ao me ver frustrado pelo fracasso na tentativa de uma boa imagem, o arcebispo Correia me pediu para que entrasse no templo e tirasse algumas fotos do Buda, mas que fizesse isso rapidamente, fazendo questão de me dar os duzentos yenes (que equivaliam, na época, a pouco menos de dois dólares) para comprar o ingresso.

Mesmo sabendo que tal estátua grandiosa não representava nada simbolicamente para a HBS, como grande conhecedor da teoria budista, o sacerdote superior permitiu que eu fosse até a estátua e a fotografasse, por causa da sua grande importância histórica para a religião japonesa.

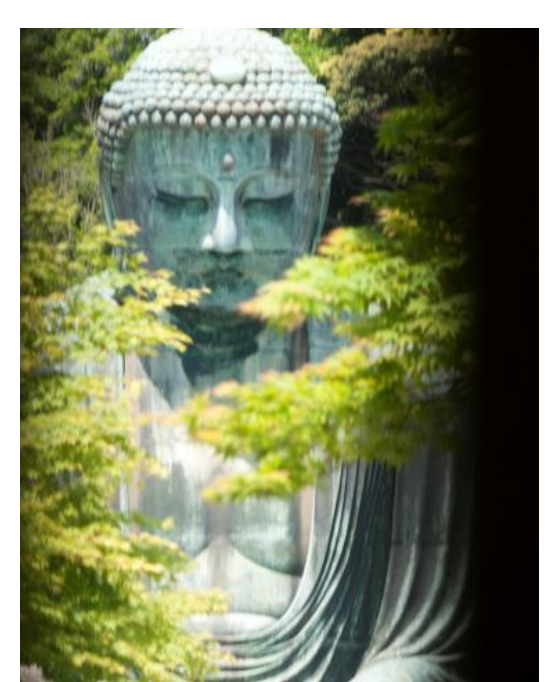

Foto 19: Fotografia tirada da parte de fora do templo Kotoku-in, em Kamakura.

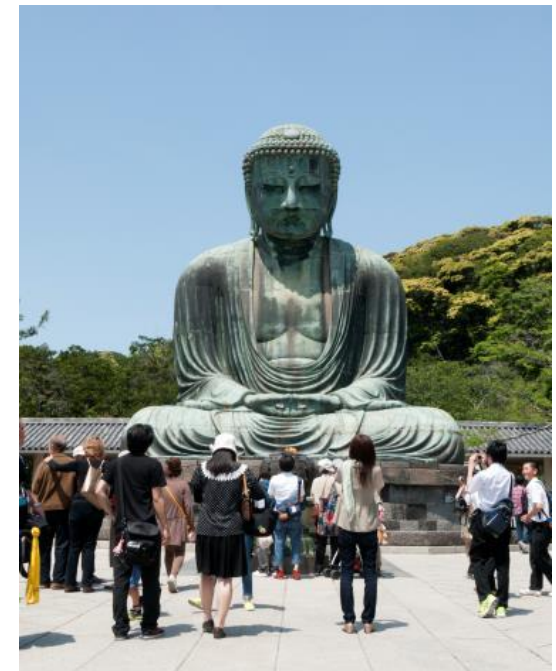

Foto 20: Imagem panorâmica do Buda Amida, pertencente à tradição Jodo-shu. 


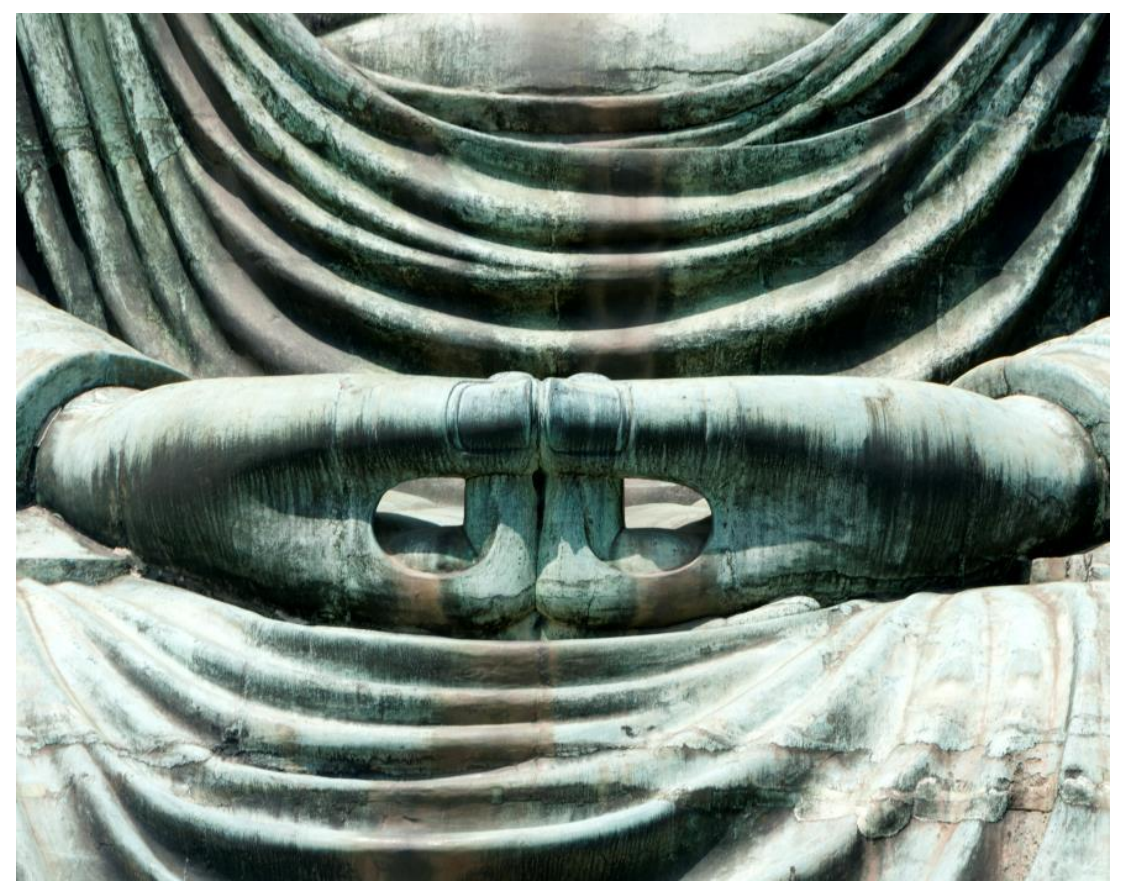

Foto 21: Close das posições das mãos da estátua do Buda Amida, em Kamakura (Japão). Esta posição representa um mudra, gesto realizado com as mãos. No caso desta estátua, o mudra em questão é o Dhyana Mudra, que representa o "Gesto de Meditação".

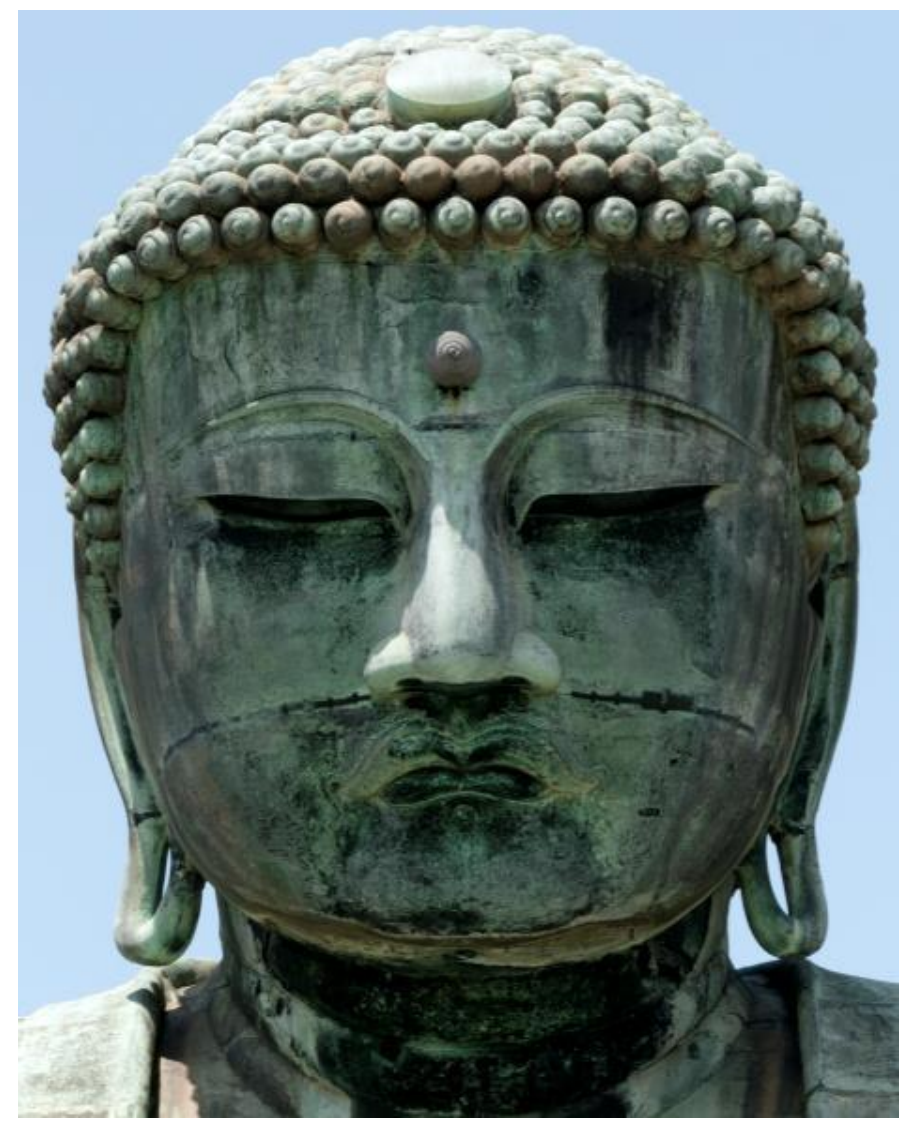

Foto 22: Close da cabeça do Buda Amida, em Kamakura, Japão. Podemos notar quatro das trinta e duas marcas presentes no corpo de um Buda: Protuberância no alto da cabeça (como se fosse um terceiro olho), cabelo encaracolado para a direita, testa larga e queixo com a "força de um leão". 


\section{Considerações finais}

No presente artigo, pretendi mostrar nuances da complexa relação estabelecida entre a comunidade estudada, a corrente budista Honmon Butsuryu-shu, e o antropólogo/fotógrafo.

Este percurso, que já dura quase quatro anos de contínua convivência, resultou em uma viagem de campo que ocorreu em maio de 2014, pelos principais locais sagrados/históricos do Budismo (na Índia e no Nepal) e por diversos templos da HBS no Japão.

O intuito da pesquisa de campo foi rel(tr)atar, com o uso predominante de imagens fotográficas, o cotidiano sagrado deste segmento do Budismo japonês, tendo como alicerce as cerimônias religiosas, que possuem como cerne o ritual de emanação, adoração e recitação do mantra e imagem sagrada, Namumyouhourenguekyou.

Uma importante questão colocada aqui é a existência de informantes privilegiados, em um sentido parecido ao colocado por Lyn Schumaker no livro “Africanizing Anthropology" (2001) quando, ao analisar o trabalho dos antropólogos do Rhodes-Livingtone Institute - que posteriormente seriam considerados os fundadores da Escola de Manchester - no contexto da colonização africana (entre 1936 e 1960), percebeu a existência fundamental do que chamou de "assistentes de pesquisa", capazes, mais do que de servirem como simples tradutores, de mediar boa parte das relações estabelecidas no campo.

No meu caso, o papel deste informante privilegiado é preenchido pelo arcebispo Correia (embora existam outros informantes fundamentais, tanto sacerdotes quanto fiéis), já que ele detém o conhecimento teórico e doutrinário da religião, domina bem o idioma japonês (falado por boa parte da comunidade no Brasil, Japão e até mesmo pelos guias indianos, que aprenderam o idioma para facilitar o trabalho com os budistas), além de exercer um papel de liderança política e institucional na HBS do Brasil.

Sem a ajuda dele, que chegou ao ponto de estabelecer para mim o lugar legitimado de "fotógrafo oficial" da caravana, possivelmente minha peregrinação não ocorreria com sucesso, tampouco seria possível a realização das fases preliminares de pesquisa, ocorridas durante o mestrado.

O intuito destas constatações é mostrar que o trabalho realizado com a comunidade budista HBS é fruto de um intenso convívio com a mesma, e a construção 
dos resultados da pesquisa de campo só foi possível nesta relação dialógica com a comunidade em questão, sempre mediada pelo arcebispo Correia, autoridade religiosa influente e respeitada, tanto por fiéis quanto pelos demais clérigos, sejam eles brasileiros ou japoneses.

Outra questão importante é pensar que, para fiéis, sacerdotes e budistas indianos e nepaleses, o que poderíamos considerar como lenda ou conto faz parte da história, tendo, para eles, comprovações científicas como, por exemplo, a existência de restos do corpo físico do Buda, localizados no Museu Nacional Mahatma Gandhi.

Neste sentido, optei por utilizar o termo mito(s), como forma de melhor representar algo que para a comunidade estudada é história factual, mas para leigos ou não convertidos é tratado apenas como lenda ou invenção. Aqui, o conceito de mito possui um caráter simbólico, imagético e, até mesmo, imaginativo, que evita que um juízo de valor pré-concebido (ou até mesmo preconceituoso) se estabeleça.

\section{Referências}

ALVES, André. Os argonautas do mangue. $1^{\text {a }}$ Ed. Campinas: Editora da Unicamp, 2004.

BATESON, Gregory. Balinese character. A photographic analysis. Nova York: The New York Academy of Sciences, 1942.

BORGES, Jorge Luiz. Buda. Rio de Janeiro: Editora Difel, 1977.

CLIFFORD, James. On ethnographic authority. In: Representations 1:2, Spring, 1983.

COLLIER, John. Antropologia Visual: A fotografia como método de pesquisa. São Paulo: Editora da Universidade de São Paulo, 1973.

CORREIA, Kyouhaku. O significado de Honmon Butsuryu-shu. 2010. Disponível em http://www.budismo.com.br/significado. php. Acesso em 20/03/2013.

ELIOT, Charles. Japanese Buddhism. Londres: Editora Routledge, 1959.

GEERTZ, Clifford. The interpretation of cultures. Nova York: Editora Basic Books, 1973.

GENNEP, Arnold van. Os ritos de passagem. Petrópolis: Editora Vozes LTDA, 1978.

GONÇALVES, Ricardo Mário. Textos Budistas e Zen-Budistas. São Paulo: Cultrix, 1967/1976. YUIEN - Tannisho - Tratado de Lamentações das Heresias.

São Paulo: Templo Higashi Honganji, 1974/1987.

Elevação, 2007. A ética budista e o espírito econômico do Japão. São Paulo:

GOODMAN, Nelson. Twisted tales: Or, Story, Study and Symphony. Chicago: University of Chicago, vol.46, n. 03, pp. 331-349, 1981.

INGOLD, Tim. Being alive: Essays on movement, knowledge and description. Nova York: Editora Routledge, 2011.

Redrawing Anthropology: Materials, Movements,Lines. Londres: Tim Ingold (Ed.), 2011.

Lines: A Brief History. Nova York: Editora Routledge, 2007.

KYÕKAI, Bukkyõ Dendõ. A doutrina de Buda. $4^{\text {a }}$ Ed. São Paulo: Fundação Educacional e Cultural Yehan Numata, 1998. 
MALINOWSKI, Bronislaw. Argonautas do pacifico ocidental: Um relato do empreendimento e da aventura dos nativos nos arquipélagos da Nova Guiné melanésia. São Paulo: Abril Cultural, 1976.

NINA, Ana Cristina Lopes. Ventos da Impermanência. São Paulo: EdUSP, 2006.

NOVAK, Philip; SMITH, Huston. Budismo: Uma introdução concisa. São Paulo: Cultrix, 2003. PEIRANO, Mariza. A análise antropológica de rituais. Brasília: Universidade de Brasília, 2000.

SCHUMAKER, Lyn. Africanizing Anthropology. Fieldwork, Networks, and the Making of Cultural Knowledge in Central Africa. Londres: Duke University Press, 2001.

SILVA, Vagner Gonçalves da. A crítica antropológica pós-moderna e a construção textual da etnografia religiosa afro-brasileira. Cadernos de Campo (USP), São Paulo, v. 1, n.1, p. 47-60, 1992.

STRASSLER, Karen. Refracted Visions. Popular photography and national modernity in Java. Londres: Duke University Press, 2010.

TURNER, Victor. Floresta de símbolos: Aspectos do Ritual Ndembu. Londres: Cornell University Press, 1967.

1974.

O processo ritual: estrutura e antiestrutura. Petrópolis: Vozes LTDA,

USARSK, Frank (org.). O budismo no Brasil. São Paulo: Editora Lorosae, 2002.

Recebido em: 28/03/2015

Aprovado em: 22/05/2015 